DOI 10.22460/infinity.v7i1.p15-24

\title{
ASSOCIATION AMONG MATHEMATICAL CRITICAL THINKING SKILL, COMMUNICATION, AND CURIOSITY ATTITUDE AS THE IMPACT OF PROBLEM-BASED LEARNING AND COGNITIVE CONFLICT STRATEGY (PBLCCS) IN NUMBER THEORY COURSE
}

\author{
Zetriuslita $^{1}$, Wahyudin', Jarnawi Afgani Dahlan ${ }^{3}$ \\ ${ }^{1}$ Universitas Islam Riau, Jl. Kaharuddin Nasution 113 Pekanbaru Riau, Indonesia \\ ${ }^{2,3}$ Universitas Pendidikan Indonesia, Jl. Setiabudi No.229, Bandung, West Java, Indonesia \\ ${ }^{1}$ zetriuslita@edu.uir.ac.id, ${ }^{2}$ wahyudin_mat@yahoo.com, ${ }^{3}$ jarnawi@upi.edu.com
}

Received: November 17, 2017 ; Accepted: January 13, 2018

\begin{abstract}
This study aims to find out the association among Mathematical Critical Thinking ability, Mathematical Communication, and Mathematical Curiosity Attitude as the impact of applying Problem-Based Learning Cognitive Conflict Strategy in Number Theory course. The research method is a correlative study. The instruments used include a test for mathematical critical thinking skill and communication, and questionnaire to obtain the scores of mathematical curiosity attitude. The findings showed that: 1) there was no association between critical thinking skill and mathematical curiosity attitude as the impact of applying problem-based learning cognitive conflict strategy, 2) there was no association between mathematical communication and curiosity attitude as the impact of applying problem-based learning and cognitive conflict strategy, and 3) the impact of applying problem-based learning cognitive conflict strategy was more influential in developing critical thinking skill than communication skill and curiosity.
\end{abstract}

Keywords: Cognitive Conflict Strategy, Communication, Critical Thinking, Curiosity Attitude, Problem-Based Learning.

\begin{abstract}
Abstrak
Penelitian ini bertujuan untuk mengetahui asosiasi kemampuan berpikir kritis, komunikasi dan sikap rasa ingin tahu (curiosity) matematis sebagai efek penerapan pembelajaran berbasis masalah berstrategi konflik kognitif dalam mata kuliah teori bilangan. Metode penelitian yang digunakan adalah penelitian korelasional. Instrumennya berupa tes untuk menjaring kemampuan berpikir kritis dan komunikasi matematis serta angket untuk memperoleh skor sikap curiosity matematis. Hasil analisis menunjukkan: (1) Tidak terdapat asosiasi antara kemampuan berpikir kritis dan sikap curiosity matematis sebagai dampak penerapan pembelajaran berbasis masalah berstrategi konflik kognitif; (2) Tidak terdapat asosiasi antara kemampuan komunikasi dan sikap curiosity matematis sebagai dampak penerapan pembelajaran berbasis masalah berstrategi konflik kognitif; (3) Penerapan pembelajaran berbasis masalah berstrategi konflik kognitif didominasi dalam pengembangan kemampuan berpikir kritis sehingga kurang berdampak terhadap kemampuan komunikasi dan sikap curiosity matematis.
\end{abstract}

Kata Kunci: Berpikir Kritis, Curiosity, Komunikasi, Pembelajaran Berbasis Masalah, Strategi Konflik Kognitif.

How to Cite: Zetriuslita, Wahyudin, \& Dahlan, J. A. (2018). Association among Mathematical Critical Thinking Skill, Communication, and Curiosity Attitude as the Impact of Problem-Based Learning and Cognitive Conflict Strategy (PBLCCS) in Number Theory Course. Infinity, 7 (1), 15-24 doi:10.22460/infinity.v7i1.p15-24 


\section{INTRODUCTION}

In education, especially Mathematics Education, Critical Thinking is a higher-order thinking skill. In Bloom's taxonomy, it consists of three levels: analysis, synthesis, and evaluation (Ennis, 1993; Duron, Limbach, \& Waugh, 2006). Johnson (2007) also stated that critical thinking is a well-directed and clear process used in mental activities such as problemsolving, decision making, persuasive activities,assumption analysis, and the ability to conduct scientific research.

Critical thinking skill can be perceived differently by many people and highly dependent on their thinking (Thompson, 2011; Hidayat, 2012). For instance, students must be able to interpret the given a problem into the mathematical sentence, solve it, evaluate the problemsolving and test or re-examine the accuracy of the answer to the given problem. Chukwuyenum (2013) stated that critical thinking is a complex concept involving cognitive skills and affective dispositions that influence the way teachers present the concepts to students. Falcione \& Falcione (1994) reinforces this idea in Aktaş, \& Ünlü (2013) that the disposition of critical thinking can help to predict the critical thinking skill. Critical thinking it also supports the intellectual curiosity. The thinking process generates one's curiosity towards the problem.

Moreover, in communication, in NCTM (National Council of Teachers of Mathematics) (2000) stated that communication is an essential part of mathematics and Mathematics Education. Students must learn mathematical communication, in addition to reasoning, and problem solving in primary and secondary education. Kadir (2013) suggested the importance of communication in Mathematics learning. A person is considered to understand something if he can explain it well, either orally or in writing.

Furthermore, the importance of mathematical communication is to the goal of education for students includes in the NCTM Standards document (NCTM, 2000). In NCTM, one of the goal of education is that students can communicate well mathematically. In the learning process, especially in mathematics learning, communication has a crucial role. If students cannot communicate, they cannot explain the meaning in mathematics if they do not understand mathematical language. According to Rahmi, Nadia, Hasibah, \& Hidayat (2017), there are three kinds of mathematical communication: communication about mathematics, communication in mathematics, and communication with mathematics.

Communication about mathematics refers to how students are able to understand the concepts of mathematics, communication in mathematics means writing symbols that can be understood from mathematics, and communication with mathematics is a verbal communication, explain what is perceived about the concept of mathematics it self.

In regards to curiosity attitude, curiosity is one of the scientific attitudes. Binson (2009) defines curiosity as the disposition to inquire, investigate, and seek after acquiring knowledge. The tendency to inquire, investigate, and seek is a thinking framework of curiosity attitude about something more deeply. The high desire for learning something or looking for answers to specific questions is the catalyst for developing someone's scientific abilities. Reio Jr, Petrosko, Wiswell, \& Thongsukmag (2006) said that curiosity is the desire for acquiring new knowledge and new sensory experience that motivates exploratory behavior. Santoso (2011) argues that curiosity or a desire to know something is the basic nature of humans who keep asking whatever they see and find before asking why or how something happens. These 
questions then continue and develop into more advanced ones by asking why a problem occurs, how something happens and how to find a solution to this problem. Such critical questions are typical to human beings and identified from the very beginning they can talk and express their feelings to other humans.

In learning, curiosity is defined as a strong motivational force that can produce someone's behavior for understanding or facing certain materials or problems. According to Santoso (2011), curiosity doesn't occur suddenly but needs to be cultivated and trained to develop. One of the ways for fostering curiosity is to provide challenging and complex problems that can create a variety of questions for students. Their curiosity can increase by making them interested in learning through demonstration at the beginning of the lessons, asking questions that are challenging for their thinking ability, or giving complicated problems hopefully that they are curious to find the answers.

Suhadak (2014) stated that curiosity is a phenomenon characterized by an effort to seek and find something which leads to enthusiasm for learning, investigating, and observing. Considering its significant role in learning, the development of curiosity should be the main focus of learning. The more curious learners feel about something, the closer they get to their learning environment, including their work groups (Binson, 2009).

Mathematical curiosity is a strong motivation that learners haveto understand the materials or mathematical problems. Curiosity about mathematical problems leads students to get the answer to the question. One way to get the answer is asking questions or inquiry. Inquiry helps students to construct their understanding independently. Understanding of concepts is obtained through constructing a better understanding compared with the acquired one. As a result, it is necessary to develop students' curiosity because it motivates them to acquire new knowledge. Mathematical curiosity means curiosity about a mathematical problem or conflict in Mathematics learning.

The relationship between critical thinking and mathematical curiosity can be seen from the characteristics. In critical thinking, questions typically occur like "What if?", "What is wrong?", and "What will we do?"Regarding curiosity, the questions will be: "Why can it be like this?", "How to solve it?" One can be assumed that curiosity contributes to someone's critical thinking about something. According to Santoso (2011), the application of ProblemBased Learning can develop creative thinking skill and curiosity. Both abilities should be well-trained because they don't occur instantly.

Curiosity heavily influences mathematical critical thinking and communication about a particular problem or situation. Facing the challenges requires critical thinking skill, mathematical communication and in-depth curiosity. Especially for mathematics in Higher Education, mathematical critical thinking, communication and curiosity are the primary assets for students in dealing with the problems, both in learning and everyday social life.

In this study, Problem-Based Learning Cognitive Conflict Strategy (PBLCCS) has been applied to develop mathematical critical thinking skill, communication, and curiosity in Number of Theory courses. The findings showed that the application of PBLCSS could significantly increase students' critical thinking skill and has not been able to increase communication skill and mathematical curiosity attitude (Zetriuslita, Wahyudin, \& Jarnawi, 2017). 


\section{METHOD}

The method of the research used correlative research. The instruments include thetest to examine students' critical thinking ability and mathematical communication and the questionnaire to obtain the scoresof curiosity attitude. The Chi-Square test is used to process the data by using software SPSS version 21.00 version. The association is measured with the Pearson correlation coefficient $\left(\mathrm{r}_{\mathrm{xy}}\right)$ with the interpretation as seen in Table 1 below :

Table 1. Interpretation to Corellation Value (Pearson correlation coefficient $\left(\mathrm{r}_{\mathrm{xy}}\right)$ )

\begin{tabular}{ll}
\hline $\boldsymbol{r}_{\boldsymbol{x}}$ Value & Interpretation \\
\hline $0.00-0.199$ & Very weak or no correlation \\
$0.20-0.399$ & Weak \\
$0.40-0.599$ & Medium \\
$0.60-0.799$ & Strong or High \\
$0.80-1.000$ & Very strong or very high \\
\hline
\end{tabular}

In order to find out whether the association is significant or not, the Chi-Square test is used with the following requirement:

The test results for mathematical critical thinking skill and mathematical curiosity

If $\operatorname{sig} \geq \alpha$, with $\left(\alpha=0.05\right.$ ), then accepted $\mathrm{H}_{0}$, meaning that there is no significant association between mathematical critical thinking skill and curiosity attitude as the impact of applying problem-based learning and cognitive conflict strategy.

If sig $<\alpha,(\alpha=0.05)$, then rejected $\mathrm{H}_{0}$, meaning that there is a significant association between mathematical critical thinking skill and curiosity attitude as the impact of applying problembased learning and cognitive conflict strategy.

\section{The test results for mathematical communication skill and curiosity}

If $\operatorname{sig} \geq \alpha$, $(\operatorname{sig} \alpha=0.05)$, then accepted $\mathrm{H}_{0}$, meaning that there is no significant association between mathematical communication skill and curiosity attitude as the impact of applying problem-based learning and cognitive conflict strategy.

2. If $\operatorname{sig}<\alpha,(\alpha=0.05)$, then rejected $\mathrm{H}_{0}$, meaning that there is a significant association between mathematical communication skill and curiosity attitude as the impact of applying problem-based learning and cognitive conflict strategy.

\section{RESULTS AND DISCUSSION}

\section{Results}

\section{Association between Mathematical Critical Thinking Skill and Curiosity}

Before discussing the association between mathematical critical thinking skill and curiosity, the hypotheses will be presented first.

$\mathrm{H}_{0}$ : There is no significant association between mathematical critical thinking skill and curiosity attitude as the impact of applying problem-based learning and cognitive conflict strategy. 
$\mathrm{H}_{1}$ : There is a significant association between mathematical critical thinking skill and curiosity attitude as the impact of applying problem-based learning and cognitive conflict strategy.

The association between mathematical critical thinking skill and curiosity was calculated using the Chi-Square test as seen in Table 2 below.

Table 2. Association of Mathematical Critical Thinking Ability And Curiosity

\begin{tabular}{llll}
\hline & Value & Df & Asymp. Sig. (2-sided) \\
\hline Pearson Chi-Square & $182.813^{\mathrm{a}}$ & 200 & 0.803 \\
Likelihood Ratio & 91.629 & 200 & 1.000 \\
Linear-by-Linear Association & 0.204 & 1 & 0.652 \\
N of Valid Cases & 25 & & \\
\hline
\end{tabular}

As Table 2 above shows Asymp.Sig. (2-sided) $=0.803 \geq \alpha$, it means that there is no association between mathematical critical thinking skill and curiosity as the impact of applying problem-based learning and cognitive conflict strategy. In other words, students with high critical thinking ability don't automatically have high mathematical curiosity either. It can be seen from the correlation coefficient in Table 2 .

Table 3. The Correlation Coefficient of Mathematical Critical Thinking Skill and Curiosity

\begin{tabular}{llcc}
\hline & & Critical Thinking & Curiosity \\
\hline Critical & Pearson Correlation & 1 & 0.092 \\
Thinking & Sig. (2-tailed) & & 0.661 \\
& N & 25 & 25 \\
\hline \multirow{3}{*}{ Curiosity } & Pearson Correlation & 0.092 & 1 \\
& Sig. (2-tailed) & 0.661 & \\
& N & 25 & 25 \\
\hline
\end{tabular}

Table 3 shows that the Pearson correlation coefficient $\left(\mathrm{r}_{\mathrm{xy}}\right)=0.092$, which means the association between mathematical critical thinking skill and curiosity is very weak, they tend to have no relationship. It can be seen in the value of contingency coefficient in Table 4 below.

Tabel 4.Significance value of mathematical critical thinking skill and curiosity

\begin{tabular}{|c|c|c|}
\hline & Value & Approx. Sig. \\
\hline Nominal by Nominal Contingency Coefficient & 0.938 & 0.803 \\
\hline $\mathrm{N}$ of Valid Cases & 25 & \\
\hline
\end{tabular}

a. Not assuming the null hypothesis.

b. Using the asymptotic standard error assuming the null hypothesis.

Table 4 shows that the absence of association can be seen from the coefficient of determination $(0.938)^{2}=0.880=88 \%$. It means that the absence of the association between mathematical critical thinking skill and curiosity is $88 \%$. For further description, see Figure 1 below. 


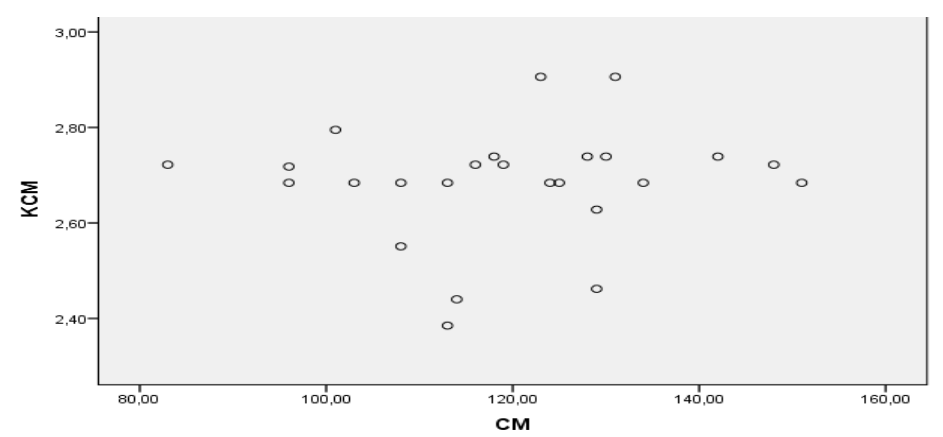

Figure 1. association between Mathematical Critical Thinking skill and Curiosity

Figure 1 above clarifies that there is no association between mathematical critical thinking skill and curiosity. The points that illustrate the KCM and CM scores scatter randomly without forming patterns, either linear orsquared pattern and so on.

\section{Association between Mathematical Communication Skill and Curiosity}

Hypothesis:

$\mathrm{H}_{0}$ : there is no significant association between mathematical communication skill and curiosity attitude as the impact of applying problem-based learning and cognitive conflict strategy.

$\mathrm{H}_{1:}$ there is a significant association between mathematical critical thinking skill and curiosity attitude as the impact of applying problem-based learning and cognitive conflict strategy.

Similar to the association between mathematical critical thinking skill and curiosity, the ChiSquare tests are also used to find out the association between mathematical communication skill and curiosity attitude.

Table 5. Association Between Mathematical Critical Thinking Skill And Curiosity

\begin{tabular}{lccc}
\hline & Value & Df & Asymp. Sig. (2-sided) \\
\hline Pearson Chi-Square & $212.708^{\mathrm{a}}$ & 200 & 0.256 \\
Likelihood Ratio & 99.441 & 200 & 1.000 \\
Linear-by-Linear Association & 2.618 & 1 & 0.106 \\
N of Valid Cases & 25 & & \\
\hline
\end{tabular}

Table 5 shows that Asymp. Sig. $(2$-sided $)=0.256 \geq \alpha$. It means that there is no association between mathematical communication skill and curiosity attitude as the impact of applying problem-based learning and cognitive conflict strategy. In other words, students with high communication skill don't automatically have high curiosity either (Table 6).

Tabel 6. Correlation Between Communication And Curiosity Ability

\begin{tabular}{llcc}
\hline & & Communication & Curiosity \\
\hline \multirow{4}{*}{ Communication } & Pearson Correlation & 1 & 0.330 \\
& Sig. (2-tailed) & & 0.107 \\
& N & 25 & 25 \\
\hline \multirow{3}{*}{ Curiosity } & Pearson Correlation & 0.330 & 1 \\
& Sig. (2-tailed) & 0.107 & \\
& N & 25 & 25 \\
\hline
\end{tabular}


Table 6 shows that Pearson Correlation $\left(r_{x y}\right)=0.330$, which means the association between mathematical communication skill and curiosity is weak. See Table 7 for details.

Table7. The Significance Value of Critical Thinking Skill and Curiosity

\begin{tabular}{|c|c|c|c|}
\hline & & Value & Approx. Sig. \\
\hline Nominal by Nominal & Contingency Coefficient & 0.946 & 0.256 \\
\hline $\mathrm{N}$ of Valid Cases & & 25 & 25 \\
\hline
\end{tabular}

a. Not assuming the null hypothesis.

b. Using the asymptotic standard error assuming the null hypothesis.

Table 7 shows that the weak relationship can be seen from the coefficient of determination of $(0.946)^{2}=0.895=89.5 \%$. It means that the absence of the association between communication skill and curiosity is $89.5 \%$. Approx. Sig $=0.256 \geq \alpha$ value means $\mathrm{H}_{0}$ is accepted. In conclusion, there is no significant association between mathematical communication skill and curiosity attitude as the impact of applying problem-based learning and cognitive conflict strategy (Figure 2).

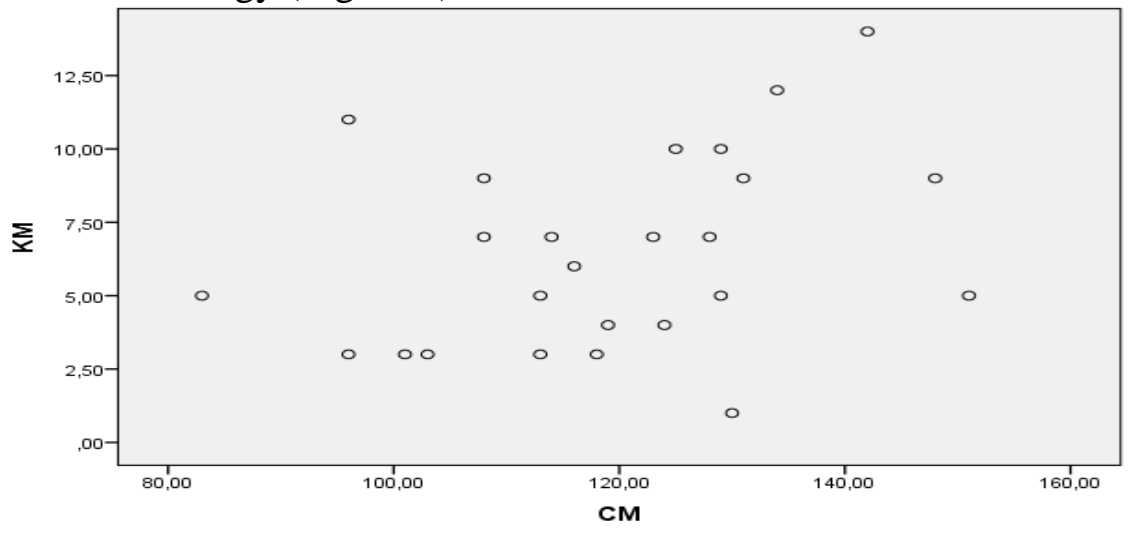

Figure2. association between Mathematical Communication and Curiosity Attitude

Figure 2 shows that the points that illustrate the scores scatter randomly, which means that there is no clear pattern, whether it is linear or something else.

\section{Discussion}

Based on the analysis for both of the hypotheses above, there was no association or relationship between mathematical critical thinking skill and curiosity, and between mathematical communication skill and curiosity as the impact of problem-based learning and cognitive conflict strategy. White (2009) commented on the adoption of Problem-Based Learning that curiosity was not teachable and rarely tested but needs to be cultivated and exercised. Consequently, Zion \& Sadeh (2010) also stated that Open Inquiry Learning can improve curiosity. In inquiry learning, students are stimulated to find out the materials, one of which is to directly ask them towork with the phenomena that exist around them. However, accordingto the findings of this study, PBLCCS was not able to develop students' curiosity. Based on the statistical data, one of the reasons is that their curiosity is quite high. Subsequently, lecturers were less focused on stimulating the students' curiosity.

Although applying problem-based learning and cognitive conflict strategy can increase critical thinking skill, it has not improved mathematical communication skill and curiosity (Zetriuslita, et al., 2017). It is an evident if critical thinking skill in creases while curiosity 
does not; it influences the association of both variables. That is why there was no association between them, as well as the association between mathematical communication skill and curiosity. The lack of effort by educators also influences the development of students' communication in learning. Another problem arose when college students were not accustomed to communicate with, in, and about mathematics, either orally or in writing.

In the implementation of learning, mathematical communication skill and curiosity were considered less important. It can be seen during the learning process. The activities were more focused on developing critical thinking skill instead of mathematical communication and curiosity.

The other issue was the lack of Learning Instruments (LI) such as student's worksheet that focuses on developing communication skill. The worksheet heavily emphasized on developing critical thinking skill. In addition, lecturers did not work harder in facilitating communication in learning. However, according to Lang \& David (2006), an educator should be a good communicator. Besides, the limitation time in this research depicted that students were still unfamiliar with the given material. They even have to get adjusted to the learning type. Apparently, college students did not acquire the "PBLCCS" spirit in a relatively short time. Maharani \& Laelasari (2017) argued that Problem-Based Learning cannot be implemented if the situation is not possible, so there must be an alternative that suits the environment in which learning takes place. According to Wang, Li, Pang, Liang, \& Su (2016), to successfully of using $P B L$, students should be responsive to the learning process. Then Rohana (2015) state that affective areas were indirect objects of mathematics, while cognitive areas are direct mathematical objects. Therefore, it requires a plenty of time and appears to be relatively slow. It affects the absence of association among the abilities as mentioned aboveafter applying problem-based learning and cognitive conflict strategy. However, if the variables were equally increasing, the relationship will automatically exist at the same time.

\section{CONCLUSION}

In the light of the preceding discussions and summary of findings, the following conclusions i.e : there was no significant association between mathematical critical thinking skill and curiosity attitude as the impact of applying problem-based learning and cognitive conflict strategy and there was no significant association between mathematical communication skill and curiosity attitude as the impact of applying problem-based learning and cognitive conflict strategy.

\section{ACKNOWLEDGMENTS}

I thank to my promoters who always gives guidance in writing this article. I also thank to Kemristekdikti who funded this research which is part of doctoral dissertation research.

\section{REFERENCES}

Aktaş, G. S., \& Ünlü, M. (2013). Critical thinking skills of teacher candidates of elementary mathematics. Procedia-Social and Behavioral Sciences, 93, 831-835..

Binson, B (2009). Curiosity based learning (CBL) program. US-China Education Review, 6(12), 13-22. 
Chukwuyenum, A. N. (2013). Impact of critical thinking on performance in mathematics among senior secondary school students in Lagos state. IOSR Journal of Research \& Method in Education, 3(5), 18-25.

Duron, R., Limbach, B., \& Waugh, W. (2006). Critical thinking framework for any discipline. International Journal of Teaching and Learning in Higher Education, 17(2), 160-166.

Ennis, R. H. (1993). Critical thinking assessment. Theory into practice, 32(3), 179-186.

Falcione, P. A., \& Falcione, N. C. (1996). The holistic CT scoring rubric. Millbrae, CA: California Academic Press.

Hidayat, W. (2012). Meningkatkan Kemampuan Berpikir Kritis dan Kreatif Matematik Siswa SMA Melalui Pembelajaran Kooperatif Think-Talk-Write (TTW). In Seminar Nasional Penelitian, Pendidikan dan Penerapan MIPA.

Johnson, E. B. (2007). Contextual teaching and learning: Menjadikan kegiatan belajar mengajar mengasyikkan dan bermakna. Bandung: Mizan Learning Center.

Kadir (2013). Mathematical communication skill of junior secondary school students in coastal area. Jurnal Teknologi. 63(2), 77-83

Lang, H. R., \& David N. E. (2006). Model, strategies and Methods for Effective Teaching. America. Pearson Education

Maharani, A., \& Laelasari, L. (2017). Experimentation of Spices Learning Strategies with the Method of Problem Based Learning (PBL) to Build Motivation and the Ability to Think Logically for Vocational School Students. Infinity Journal, 6(2), 149-156.

NCTM. (2000). Principles and standards for school mathematics. USA: The National Councils of Teachers of Mathematics.

Rahmi, S., Nadia, R., Hasibah, B., \& Hidayat, W. (2017). The Relation between Self-Efficacy toward Math with the Math Communication Competence. Infinity Journal, 6(2), 177182.

Reio Jr, T. G., Petrosko, J. M., Wiswell, A. K., \& Thongsukmag, J. (2006). The measurement and conceptualization of curiosity. The Journal of Genetic Psychology, 167(2), 117135 .

Rohana, R. (2015). Peningkatan Kemampuan Penalaran Matematis Mahasiswa Calon Guru melalui Pembelajaran Reflektif. Infinity Journal, 4(1), 105-119.

Santoso, F. G. I. (2011). Mengasah kemampuan berpikir kreatif dan rasa ingin tahu melalui pembelajaran matematika dengan berbasis masalah (suatu kajian teoritis). In Prosiding Seminar Nasional Matematika dan Pendidikan Matematika FMIPA UNY.

Suhadak, M. (2014). Keefektifan metode inkuiri dalam pembelajaran sistem persamaan linear dua variabel ditinjau dari prestasi dan curiosity. Indonesian Digital Journal of Mathematics and Education, 1(1).

Thompson, C. (2011). Critical thinking across the curriculum: Process over output. International Journal of Humanities and social science, 1(9), 1-7.

Wang, Q., Li, H., Pang, W., Liang, S., \& Su, Y. (2016). Developing an integrated framework of problem-based learning and coaching psychology for medical education: a participatory research. BMC medical education, 16(1), 2. 
White, H. B. (2009). Commentary: Cultivating students' curiosity quotient with problembased learning. Biochemistry and Molecular Biology Education, 37(4), 249.

Zetriuslita, Z., Wahyudin, W., \& Jarnawi, J. (2017). Mathematical Critical Thinking and Curiosity Attitude in Problem Based Learning and Cognitive Conflict Strategy: A Study in Number Theory course. International Education Studies, 10(7), 65.

Zion, M. I., \& Sadeh, I. (2007). Curiosity and open inquiry learning. Journal of Biological Education, 41(4), 162-169. 